\title{
ИНТЕРАКТИВНИ ЧАСОПИСИ. ПРИКАЗ МАРТОВСКИХ БРОЈЕВА ЧАСОПИСА ЗА ДЕЦУ ОСНОВНОШКОЛСКОГ УЗРАСТА У ИЗДАҢУ НОВЕ ШКОЛЕ.
}

Укупна издавачка делатност у Србији и региону броји само пет часописа за децу основношколског узраста. Покренути од стране Нове школе са средиштем у Београду, „Школарка” (1 и 2, за први и други разред), „Школарац” (3 и 4, за наредна два разреда) и „Нај нај” (за други циклус образовања у основним школама) имају иза себе око сто педесет бројева и квалитет који само добија на свом значају у сваком новом месечном броју. Анализирајући их, показује се да постоји јак континуитет у структури ових часописа, али су прилагођени и деци која се нису у претходним разредима сусретала са њима. Тако, ученик четвртог разреда може наћи исто уживање и корист од „Школарца 4” као и ученик првог разреда у „Школарки 1”.

Уз обим од преко тридесет страница, сваки од илустрованих часописа у боји доноси и додатни поклон/материјал. „Школарка 1” овог месеца поклања три басне, две екавског наречја и једну ијекавског, на формату који се развлачи, као и картонске картице са сезонским цвећем и стихованим описима истих на полеђини. Часопис се отвара репродукованим цртежима деце који су стигли на адресу редакције и у средини има игру Пролећна забава која се може истргнути из остатка часописа како би била приступачнија за играче од којих највише може бити четири. Сам часопис је издељен у петнаест области и сваки број странице је украшен илустрацијом пужа, сунцокрета, ротквице, бубамаре, вишњице, лептирића и сл. За разлику од часописа за старије узрасте, „Школарка 1” је готово цела у илустрацијама и само један сегмент, Животињско царство, садржи фотографије. Уз изузетан графички дизајн, у остале области спадају То сам ја - то смо ми (о 
породици и друштвеним односима), Школа је извор знања и Моје огледало које у овом броју доноси изузетно вредну лекцију о томе како се користи аутобус и како се понаша у њему.

Захваљујући оваквим лекцијама које недостају систему основног образовања код нас, смањује се разлика са образовним програмима у Европској Унији, а међу којима се шведски наводи као најпрактичнији и најкориснији за свакодневни живот. Ту су и област Словоиграоница, затим Истражујем и упознајем природу у којој је предвиђен простор за цртање, као и Знање је игра - знање је моћ. У том делу је математика представљена на интересантан и сликовит начин тако да сваком броју одговара нека животиња и у њиховим скуповима од деце се тражи да нађу двоцифрене збирове. Уз вежбе за писање писаним словима, за разумевање текста уз питања за разговор и простор за исписавање одговора, „Школарка 1” садржи и области Ја читам, Баш је лако правити овако (упутства за прављење цветова од папира у боји), народне изреке и умотворине, причу у сликама на основу које деца треба да саставе текст, Учионицу играоницу о описима неких занимања, као и део са бојењем и сабирањем, лавиринтом, задацима за уочавање разлика међу цртежима и веселим мозаиком који може да се споји у једну целину.

„Школарка 2” је структурално иста као и њена претходница, али садржи више текста, фотографија и сложеније задатке. Поклон у овом броју је седам Езопових басни (у којима су заступљена оба наречја), али се даје и биографија писца. Додатне картице које се добијају са часописом представљају врсте четинара које расту у нашим шумама, али и уводе сложенији речник употребом речи „декоративно” и „симбол”. Прилози су о школском бонтону, вежбању таблице множења, укрштене речи, ребуси, али и приче о особинама ликова о којима се може водити дискусија. Уз лекцију из екологије, овај број доноси у 
средини корпуса и игру парни-непарни, сликовни нотни систем за песму пролеће у ком је дужина ноте представљена величином једног весника пролећа - љубичицом. У вези са животињским царством се може сазнати како се родитељи брину о својим младунцима.

Иновативност коју доноси „Школарац 3” представља Школарчева лектира и у мартовском броју је то књижица „Шта је измислила моја мама". Обима око тридесет страна, књижица је визуелно успешно и лепо решена стилизацијама у нијансама розе боје, док текстове чине песме Ћопића, Змаја, Бранка Радичевића, Драгана Радуловића, Мире Алечковић, Гвида Тартаље, Десанке Максимовић, Исмета Бекића и других. Додатак је материјал за прављење беџева за осми март намењеним мами, баки, тетки, стрини, учитењици, теткици у школи или некој другој ососби из окружења детета. Можда се највећа разлика од часописа намењеним нижим разредима и као најбољи пример прилагођености том узрасту може истаћи насловни приказ маскоте Школарца који игра тенис. Слично, унутар броја може се наћи репродукција слике Густава Климта, али и поједностављен приказ конвенције о дечијим правима. Осим тога, овај број доноси и причу из грчке митологије, занимљиво конципиране лекције-приче о падежима, мозгалице, вицеве и „разгледницу” Краљева.

„Школарац 4” садржи већи број занимљивих и текстуално обимнијих чланака од претходно анализираних часописа, који убрајају прилоге о Шкотској, о млечним призводима, о добијању каучука, необичној храни из егзотичних земаља попут шкорпиона и пацова, али и илустроване лекције о грађењу речи. Док мартовски број „Школарца 4” доноси избор из Егзиперијевог Малог принща на преко тридесет страна, овомесечни број „Нај нај” часописа поклања Пустоловине Божићног пудинга од Агате Кристи на издуженом формату са ког се лакше и брже чита. Ово је уједно и најзначајнији 
део часописа, али он садржи и поклон-постере, приказе значајних књига (Десанка Максимовић, Данијел Дефо) и чланке о сезонским спортовима.

Часописис за децу Нове школе имају дозволу од Министарства просвете Републике Србије да буду кориштени у настави, али могу бити и од великог значаја за индивидуални рад деце код куће. Нема сумње да бацају ново светло на приступ образовању деце овог узраста и да ће флексибилношћу и стручношћу тима који ради на креирању нових бројева наставити да држе корак са генерацијама које већ на почетку основношколског образовања преферирају компјутерске игрице наспрам књига и часописа. Материјали Нове школе од раног детињства уче децу о свим вредностима и лепотама комуникационих медија.

Соња Р. Јанков jankovsonja@gmail.com (Факултет политичких наука, Београд - Културологоија, мастер) (Музеј савремене уметности Војводине) 